\title{
THE ARCTIC REGION, EUROPEAN UNION AND CLIMATE CHANGE, AS A GLOBAL THREAT TO SECURITY
}

\author{
Assoc.Prof. Mihaiela BUȘE, PhD*
}

\begin{abstract}
The Arctic region, on one hand, an area situated so far from the European Union and, on the other hand, an environment so hostile to life, is în the spotlight of the world's powers. The resources, so necessary for the nations, - the riches în the depths of the soil and în the ocean -, the potential of tourism and the importance of shorter transport routes aroused the interest of some actors in the region. The European Union has developed a policy for the Arctic region. Are the European Union's concerns strictly related to security and the economy or is there a much wider horizon of goals to be achieved?
\end{abstract}

Keywords: The Arctic region; European Union; globalization; climate change; threat; international security.

\section{Why is the Arctic region important for the European Union?}

The Arctic, an extensive far away region, located "at the northernmost part of the planet", despite very challenging conditions of life and climate, is arousing more and more interest globally. The Arctic region is characterized by extreme climatic peculiarities: very large temperature fluctuations, heavy snow, brief summers, large areas covered with ice, substantial discrepancies in terms of light periods. It is an extremely harsh living environment but to which both the fauna and the indigenous populations have managed to adapt ${ }^{2}$. Although it is an extremely tough environment which makes it difficult to explore, the Arctic region stores special natural resources.

Not only the important natural resources of the Arctic have generated an increased attention to this region from the countries of the world. According to the research activity realized for Arctic Human Development Report. Regional Processes and Global Linkages during 2004 (when the first report was published) - 2014 (when the second report was published) the authors state that "we have witnessed a dramatic increase in interest in the Arctic"3. This unprecedented interest of the international community was due on one hand to economic reasons and on the other hand to environmental reasons. In this order of ideas, it is necessary to mention the possibility of exploiting the enormous

\footnotetext{
**"Carol I" National Defence University

e-mail: buse-mihaela@yahoo.com
}

natural resources as well as the opening of new navigation routes that would ensure a faster transport of goods in various parts of the world. Climate change, which is devastatingly affecting the region, is also a matter of concern to countries around the world, these being, also affected by climate change occurred increasingly intensified in the Arctic ${ }^{4}$.

According to the Joint communication to the European Parliament and the Council. An integrated European Union policy for the Arctic, the EU's concern about the Arctic refers to the fact that, first of all: "A safe, stable, sustainable and prosperous Arctic is important not just for the region itself, but for the European Union (EU) and for the world"s. This way, the importance of the Arctic is underlined not only locally but also for the EU and for the whole world. Consequently, given the importance of the Arctic region for the EU, it is natural that UE become an actor involved in issues related to the Arctic and international cooperation: "The EU has a strategic interest in playing a key role in the Arctic region"6. Secondly, "Eight states have territories in the Arctic: Canada, the Kingdom of Denmark, Finland, Iceland, Norway, Russia, Sweden and the United States. Three EU Member States are therefore also Arctic states, while Iceland and Norway are members of the European Economic Area". With member countries with territories in the Arctic, the EU's interest in peace, stability and prosperity in this region is strategic.

The Ambassador for the Arctic, Michael Mann, summarizes the reasons why the Arctic 
region is important not only for the EU but also for the world as a whole, given that the effects of climate change are much more pronounced in the Arctic region than in other parts of the globe ${ }^{8}$. With three member states that have territories in the Arctic, the European Union perceives this region from the perspective of internal security rather than foreign security or foreign policy. So here is a first, extremely important reason that highlights the EU's interest in the Arctic. A second reason is that the Arctic is very important for the EU, for products like oil, gas, fish, and, in the long run, the exploitation of minerals is also being considered. The third reason is a paradox: on one hand, the EU, due to the developed industry, is one of the factors that causes the effects of climate change, and on the other hand, the EU is the main international player in the fight against climate change. Consequently, EU action to protect the Arctic seeks both to protect its own interests and to protect the planet.

\section{The global effects of climate change affecting} the Arctic - a challenge for the European Union

Over time, there have been two approaches to climate change: either non-existent or real, with devastating consequences for the environment and thus for humans. In March 2008, The European Union, through the voices of the High Representative and the European Commission, stated that climate change is not only real but already has effects on EU security and international security. Climate change is perceived as "a threat multiplier which exacerbates existing trends, tensions and instability"9. In November that year, the European Commission stated that the Arctic region is essential for the planet's climate but at the same time exposed to the effects of climate change. Thus, a cause for concern is represented by the temperatures twice as high than anywhere in the world. In addition, the accelerated melting of the ice sheet on the soil but also of the ice that covers important parts of the ocean influences the entire globe by increasing sea levels ${ }^{10}$.

Arctic ice monitoring has revealed that the effects of global warming are much more severe than anticipated. Thus, the new data show that "the Arctic Ocean could be largely free of sea ice in summer as early as the late 2030 s, only two decades from now"11. Also, contrary to previous estimates, "the recent recognition of additional melt processes affecting Arctic and Antarctic glaciers, ice caps, and ice sheets suggests that low-end projections of global sea-level rise made by the Intergovernmental Panel on Climate Change (IPCC) are underestimated" 12 . Satellite measurements revealed that "over the period 1979-2020, the sea ice area in the Arctic decreased by $33.000 \mathrm{~km}^{2}$ per year in winter (measured in March) and by $79.000 \mathrm{~km}^{2}$ per year in summer (measured in September)" "13. The trend in terms of melting ice is a continuous acceleration which is having effects both in the EU and around the globe. Thus, only "the cumulative ice loss from Greenland from 1992 to 2017 was 3.900 billion tones, [...] contributed approximately $11 \mathrm{~mm}$ of the global sea level rise" ${ }^{\prime 14}$.

High Representative/Vice-President Josep Borrell, aware of the tremendous importance of the Arctic for the EU but also for the whole world, stated that "the European Union's engagement in Arctic matters is key for our foreign policy in many ways" 15 . That is why the EU is determined to help solve the problems that the Arctic is facing. In this sense, the Arctic policy has been continuously adapted and developed. In 2021, the EU Arctic policy provides three directions of action: "firstly, to preserve the Arctic as a region of peaceful cooperation; secondly, slow the effects of climate change; and thirdly, to support the sustainable development of Arctic regions to the benefit of future generations"16. This three key aims at both short and medium-term and long-term goals because actions to mitigate the effects of climate change and sustainable development can give future generations the opportunity to enjoy the legacy we have received from our forefathers.

\section{The EU role in addressing the environmental challenges}

The Arctic faces far greater global warming consequences than other regions of the globe. According to Josep Borell, "regardless of the current pandemic, climate change remains the biggest global challenge that humanity is facing. This is especially true for the Arctic"17. As the EU is directly interested in the Arctic being a protected region in all respects: from the point of view of global warming, the economy, the protection of natural resources, it has been concerned about issues affecting its security. Thus, since 2008, the EU has distinguished itself through various initiatives 
on the Arctic region: Communication from the Commission to the European Parliament and the Council - The European Union and the arctic region $^{18}$, EU policy towards the Arctic region ${ }^{19}$, Joint Staff Working Document - The inventory of activities in the framework of developing a European Union Arctic Policy - Accompanying the document Joint Communication to the European Parliament and the Council - Developing a European Union Policy towards the Arctic Region: progress since 2008 and next steps ${ }^{20}$, Joint Communication to the European Parliament and the Council. An integrated European Union policy for the Arctic ${ }^{21}$. The last document, Joint Communication on an integrated EU policy for the Arctic, published by the European Commission and the High Representative on 27 April 2016 focuses on three priorities: climate change and the Arctic environment, sustainable development in the Arctic, international cooperation on Arctic matters.

Regarding the first priority, the EU is a leading contributor to Arctic research. On one hand, it funds research-related initiatives (40 million EUR under the 2016-2017 work program), on the other hand, it supports research projects such as the EU-PolarNet initiative. Also EU space programs will be used in research on the effects of climate change on the Arctic. Moreover, through the Paris agreement, another EU initiative to mitigate the effects of climate change, it aims to limit global temperatures below $2{ }^{\circ} \mathrm{C}$. To this end, the EU aims "to reduce its total greenhouse gas emissions by $40 \%$ by 2030 and by $80 \%$ by 2050 compared to 1990 levels" $" 22$. In addition, the EU is working "to limit emissions of short-lived climate pollutants such as black carbon and methane"23. Also, in order to protect the environment and implicitly the Arctic region, the EU respects its commitments under multilateral environmental agreements. In this regard, the EU envisages international cooperation in finding ways to protect biodiversity, in establishing marine protected areas in the Arctic, as well as measures against invasive alien species.

The second priority, sustainable development in the Arctic, is a necessity for people in such a hostile region in terms of temperatures and environment. The innovative technologies will generate great social and economic benefits. In the EU's vision "in addition to Horizon 2020, the
ESIF programmes provide funding for research and innovation activities in the European part of the Arctic"24. Investments are essential for development, so the Investment Plan for Europe can finance infrastructure projects in the Arctic: "Through this instrument and its existing lending operations, the European Investment Bank (EIB) could not only help to finance projects to improve transport connections over land, sea and air, but also telecommunications, energy efficiency projects and low-carbon technology"25. Also, the EU-owned space technology, the Copernicus program and the European Global Navigation System, will be used for security and environment monitoring purposes in the Arctic.

The third priority in the Arctic is primarily the involvement of the EU in collaboration with international organizations and fora, the UN Convention on the Law of the Sea, and participation in the Arctic Council. Secondly, the EU is involved in regional and sub-regional cooperation. Thirdly, the EU maintains a constant dialogue with Arctic indigenous peoples in order to respect human rights and to cooperate in areas where it is considered necessary.

\section{Conclusions}

According to Michael Mann, Ambassador for the Arctic, the European Union is in the Arctic. From this perspective, the EU has a strategic interest in the Arctic, both in terms of internal security and in terms of economics due to the various natural resources that are currently exploited (such as fish, oil) and those that will be exploited in the future (various minerals). In addition, the fragile Arctic environment is much more vulnerable than the rest of the planet to global warming.

That is why the EU, one of the most active actors involved in climate change mitigation, has created a policy for the Arctic that it has developed continuously because, from an EU perspective, a safe and prosperous Arctic is not just a benefit for the EU, but also for the whole world. The melting of the ice cap has effects not only in the Arctic region and does not involve severe climate change only regionally but globally. In addition, very low temperatures and the environment are characteristics of a daily life lived in difficult conditions for the indigenous populations. 
All these issues, from global warming to the social and economic difficulties of indigenous peoples, are addressed in the EU's Arctic policy. The EU identifies many directions for action both for the sustainable development of the Arctic and for the global threat posed by climate change. However, the approaches to these issues, in order to generate satisfactory results, involved international cooperation. As an example, the EU's efforts to limit global warming alone are not enough to slow the evolution of climate change. As specified in many official EU documents, global challenges can only be addressed through global efforts.

\section{NOTES:}

1 [European Union External Action Service], EU Arctic policy, 20.02.2017, https://eeas.europa.eu/headquarters/ headquarters-homepage/20966/eu-arctic-policy_en, accessed on 12.02.2021.

2 *** UN Environment programme, https://www. unep.org/explore-topics/oceans-seas/what-we-do/workingregional-seas/regional-seas-programmes/arctic-region, accessed on 03.03.2021.

3 Joan Nymand Larsen, Gail Fondahl, Arctic Human Development Report: Regional Processes and Global Linkages.Copenhagen, Nordisk Ministerråd, 2014, p. 29.

4 Ibidem.

5 *** Joint Communication to the European Parliament and the Council. An integrated European Union policy for the Arctic,, Brussels, 27.4.2016, JOIN(2016) 21, finalhttps:// eeas.europa.eu/archives/docs/arctic_region/docs/160427 joint-communication-an-integrated-european-union-policyfor-the-arctic_en.pdf, accessed on 22.02.2021.

6 Ibidem.

7 Ibidem.

8 Why does the Arctic matter to us? Ambassador for the Arctic, Michael Mann, explains in 60 seconds, 02/02/2021, https://eeas.europa.eu/headquarters/headquartershomepage/92597/why-does-arctic-matter-us-ambassadorarctic-michael-mann-explains-60-seconds en, accessed on 24.02.2021.

$9 * * *$ Climate change and international security, Paper from the High Representative and the European Commission to the European Council, 14 March 2008, https://www. consilium.europa.eu/uedocs/cms_data/docs/pressdata/en/ reports/99387.pdf

10 [European Union External Action Service], Communication from the Commission to the European Parliament and the Council - The European Union and the Arctic Region, Commission of the European Communities, Brussels, 20.11.2008, https://eeas.europa.eu/archives/ docs/arctic_region/docs/com_08_763_en.pdf, accessed on 12.01.2021.

$11 * * *$ The Arctic Monitoring and Assessment Programme (AMAP), Snow, Water, Ice and Permafrost in the Arctic. Summary for Policy-makers, Oslo, Norway, 2017, p. 3. 12 Ibidem.
13 [European Environment Agency], Indicator assessment, 8 Dec. 2020, https://www.eea.europa.eu/dataand-maps/indicators/arctic-sea-ice-4/assessment, accessed on 14.02.2021.

14 [European Environment Agency], Indicator assessment, Greenland and Antarctic ice sheets, https:// www.eea.europa.eu/data-and-maps/indicators/greenland-icesheet-4/assessment, accessed on 14.02.2021.

15 [European Union External Action Service], Arctic: Speech by High Representative/Vice-President Josep Borrell at the Arctic Frontiers conference, Brussels, 02.02.2021, https://eeas.europa.eu/headquarters/headquarters-homepage/ 92475/arctic-speech-high-representativevice-presidentjosep-borrell-arctic-frontiers-conference_en, accessed on 16.02.2021.

16 Ibidem.

17 [European Union External Action Service], The Arctic, a key region for the EU and global security, 03.02.2021, https:// eeas.europa.eu/headquarters/headquarters-homepage/92500/ arctic-key-region-eu-and-global-security_en, accessed on 08.02.2021.

$18 * * *$ Communication from the Commission to the European Parliament and the Council - The European Union and the arctic region /* COM/2008/0763 final */, https://eur-lex.europa.eu/legal-content/EN/TXT/?uri= CELEX\%3A52008DC0763

19 *** EU policy towards the Arctic region, 2012, https://eur-lex.europa.eu/legal-content/EN/LSU/?uri= CELEX\%3A52012JC0019

20 *** Joint Staff Working Document - The inventory of activities in the framework of developing a European Union Arctic Policy - Accompanying the document Joint Communication to the European Parliament and the Council - Developing a european Union Policy towards the Arctic Region: progress since 2008 and next steps, 26.06.2012, https://ec.europa.eu/transparency/documents-register/ detail?ref $=\mathrm{SWD}$ (2012)182\&lang= $\mathrm{EN}$

$21 * * *$ Joint Communication to the European Parliament and the Council. An integrated European Union policy for the Arctic, Brussels, 27.4.2016, JOIN(2016) 21, https://eeas. europa.eu/archives/docs/arctic_region/docs/160427_jointcommunication-an-integrated-european-union-policy-forthe-arctic_en.pdf, accessed on 22.02.2021.

22 Ibidem, pp. 6-7.

23 Ibidem, p. 7.

24 Ibidem, p. 10.

25 Ibidem, p. 11.

\section{REFERENCES}

*** Communication from the Commission to the EuropeanParliamentandtheCouncil-TheEuropean Union and the arctic region /* COM/2008/0763 final*/, https://eur-lex.europa.eu/legal-content/EN/ $\mathrm{TXT} /$ ?uri=CELEX\%3A52008DC0763

*** Climate change and international security, Paper from the High Representative and the European Commission to the European 
Council, 14.03.2008, https://www.consilium. europa.eu/uedocs/cms_data/docs/pressdata/en/ reports/99387.pdf

*** EU policy towards the Arctic region, 2012, https://eur-lex.europa.eu/legal-content/EN/ LSU/?uri=CELEX\%3A52012JC0019

*** Joint Staff Working Document - The inventoryofactivitiesin the frameworkof developing a European Union Arctic Policy - Accompanying the document Joint Communication to the European Parliament and the Council - Developing a european Union Policy towards the Arctic Region: progress since 2008 and next steps, 26.06.2012, https://ec.europa.eu/transparency/documentsregister/detail? $\mathrm{ref}=\mathrm{SWD}$ (2012)182\&lang $=\mathrm{EN}$

*** Joint Communication to the European Parliamentand the Council.AnintegratedEuropean Union policy for the Arctic, Brussels, 27.04.2016, JOIN(2016) 21, finalhttps://eeas.europa.eu/ archives/docs/arctic_region/docs/160427_jointcommunication-an-integrated-european-unionpolicy-for-the-arctic_en.pdf

*** The Arctic Monitoring and Assessment Programme (AMAP), Snow, Water, Ice and Permafrost in the Arctic. Summary for Policymakers, Oslo, Norway, 2017.

*** UN Environment programme, https:// www.unep.org/explore-topics/oceans-seas/whatwe-do/working-regional-seas/regional-seasprogrammes/arctic-region

*** "Why does the Arctic matter to us?", Ambassador for the Arctic, Michael Mann, explains in 60 seconds, 02.02.2021, https://eeas.europa.eu/ headquarters/headquarters-homepage/92597/whydoes-arctic-matter-us-ambassador-arctic-michaelmann-explains-60-seconds_en
[European Environment Agency], Indicator assessment, 08.12.2020, https://www.eea.europa. eu/data-and-maps/indicators/arctic-sea-ice-4/ assessment

[European Environment Agency], Indicator assessment, Greenland and Antarctic ice sheets, https://www.eea.europa.eu/data-and-maps/indicato rs/greenland-ice-sheet-4/assessment

[European Union External Action Service], Communication from the Commission to the European Parliament and the Council - The European Union and the Arctic Region, Commission of the European Communities, Brussels, 20.11.2008, https://eeas.europa.eu/archives/docs/ arctic_region/docs/com_08_763_en.pdf

[European Union External Action Service], Arctic: Speech by High Representative/VicePresident Josep Borrell at the Arctic Frontiers conference, Brussels, 02.02.2021, https://eeas. europa.eu/headquarters/headquarters-homepage/ 92475/arctic-speech-high-representativevicepresident-josep-borrell-arctic-frontiers-confer ence en

[European Union External Action Service], The Arctic, a key region for the EU and global security, 03.02.2021, https://eeas.europa.eu/headquarters/ headquarters-homepage/92500/arctic-key-regioneu-and-global-security_en

[European Union External Action Service], EU Arctic policy, 20.02.2017, https://eeas.europa. eu/headquarters/headquarters-homepage/20966/ eu-arctic-policy_en

Larsen Joan Nymand, Fondahl Gail, Arctic Human Development Report: Regional Processes and Global Linkages, Nordisk Ministerråd, Copenhagen, 2014. 